Dilemmas 2015 Papers from the 18th annual International Conference Dilemmas for Human Services: Organizing, Designing and Managing

\title{
The Complexity of Teachers' Use of Digital Technologies in Everyday School Practice
}

Sadaf Salavati

Faculty of Technology, Department of Informatics, Linnaeus University, Sadaf.Salavati@Inu.se

\begin{abstract}
The doctoral research, briefly presented in this paper ${ }^{1}$, include four teachers, two school leaders, three representatives from the Department of Education and head of the municipal IT-unit. The research followed a focused ethnographic approach, and has applied Systems Thinking, specifically Soft Systems Methodology in combination with Cognitive Mapping with the aim to illuminate and advance the understanding of the complexity of teachers' everyday practice using digital technologies.

Major investments have been done in Sweden providing and equipping schools with digital technologies. However, the digital technologies are reported not being fully used to support teaching and learning, but are mainly used as administrative tools. In order to enable teachers to fully adopt and use of digital technologies it is crucial to understand their worldviews, their everyday practice, as well as external influences and underlying perspectives.
\end{abstract}

Key words: Cognitive Mapping, compulsory school education, focused ethnography, Soft Systems Methodology, Systems Thinking, teachers

\footnotetext{
${ }^{1}$ This paper presents an updated version of a paper presented at the Dilemmas Doctoral Consortium September 2015.

(C) 2015 Sadaf Salavati. This is an Open Access article distributed under the terms of the Creative Commons Attribution-NonCommercial 4.0 International License (http://creativecommons.org/licenses/by-nc/4.0/), permitting all non-commercial use, distribution, and reproduction in any medium, provided the orig-inal work is properly cited.

http://dx.doi.org/10.15626/dirc.2015.15
} 


\section{Introduction and Background}

Reality of education cannot be found in either books, laboratories, or even in classrooms where teaching and learning takes place (Dewey, 1929). Reality of education can only be found in the thoughts and minds of those engaged in the educational practices. A number of researchers (e.g. Tondeur et al., 2008; Geertsema, 2014) argue teachers' beliefs and how teachers' see their role as being professionals need to be taken into consideration for adoption of educational innovations. Tondeur et al. (2008) argue teachers easier accept innovations in accordance with their personal thoughts and ideas about teaching and learning. From a broader perspective society and everyday lives of humans is changing radically due to the wide and ubiquitous existence of digital technologies (Bradley, 2006; Digitaliseringskommissionen, ${ }^{2}$ 2015). Various technologies can be found in Swedish school classrooms, however, the technologies are used very limited and not to its full potential (Skolinspektionen, 2012; Skolverket, 2013; Skolverket, 2016). Reports from the European Commission, the Swedish government and the Swedish National Agency for Education acknowledge use of digital technology in school education (Näringsdepartementet, 2011; SFS, 2010:800; Skolverket, 2011; Skolverket, 2016). The importance of digital technology in education has also been addressed by research scholars (e.g., Dillenbourg, Järvelä and Fischer, 2009; Grönlund, 2014; Laurillard, 2012; Scardamalia, et al., 2010), arguing for technology integration in teaching and learning in order to prepare youngsters for the $21 \mathrm{st}$ century knowledge society.

History of education and technology goes as far back as 2500 years (Bates, 2015) and oral communication has been the first means for education. Throughout evolution of time various technologies have been developed to support the oral communication. Several scholars (e.g., Bates, 2015; Laurillard, 2012) argue digital technologies used in classrooms throughout time have not initially been developed for educational purposes. Digital technologies are merely showed in to classrooms with hope that teachers will use the technology eventually; marginally improving the teaching, and to cover up lack of technology enhanced pedagogical models (Bates, 2015; Christiansen, Horn and Johnson, 2008; Grönlund, 2014; OECD, 2010; Papert and Solomon, 1972). Grönlund (2014) argue school education is no longer purely about access to digital technologies but rather the pedagogics and learning perspectives.

Various scholars (e.g., Gibson, 2001; Sharples, Taylor and Vavoula, 2007; Bates, 2015) argue implementation and use of digital technologies changes the relationships with traditional tools in the classrooms, it changes the teacher role, and it also influence teachers' relationship to their students and their professional roles. An example given by Gibson (2001), teachers' that use digital technologies in a wider extent tend to feel more professional since they can help students to

${ }^{2}$ The Swedish Digital Commission 
learn rather than purely transfer knowledge (Gibson, 2001). Gibson (2001) further argues use of digital technologies impact teachers' beliefs and mindsets, were teachers who mainly use variations of traditional pedagogy and didactics tend to question their beliefs. In order for teaching to become successful Mishra and Koehler (2008) argue the three knowledge bases: (1) Pedagogy, (2) Content, and (3) Technology, need to be in a balanced dynamic interaction. The relationship and integration between these knowledge domains make up variations seen in the integration of digital technologies in education (Mishra and Koehler, 2008). Technologies do not merely represent a single pedagogical orientation, but it rather offers varieties of approaches to teaching and learning (Bates, 2015).

The educational practice is highly complex and consists of several actors, roles, entities, and relationships, all with different power and influencing effects. The teachers are within the complex problematic situation central to the adoption and use of the digital technologies (Salavati, 2013; Gaffney, 2010). Griffin (2003) acknowledges digital technology to be powerful for teaching but argue teacher to ultimately influence the enhancement of the learning environment. He argues teachers' skills and enthusiasm define and determines whether digital technology will be useful and effective; it is about how the technology is used by teachers' to their benefit (Griffin, 2003). Grönlund (2014) claim a need to investigate and explore how learning process has changed, and how schools are conducing work differently these days? What the teachers do differently and why these ways are, or are not, better? (Grönlund, 2014, p. 19).

\section{Research Aim}

Gaffney (2010) describe the adoption and use of digital technology by teachers to consist of two dimensions: understanding teachers' multi-dimensional profession and understanding of external influences. He argues the nature of teachers' situation adopting and using digital technologies is complex, dynamic and contextual; it is "wicked".

Researching teacher's worldview insight can be gained in what they consider to be teaching and learning and how this is carried out in everyday practice both with and without use of digital technologies. Additionally, there is a need to shed light at underlying perspectives in order to gain understanding of the situation as a whole.

The aim of this research is therefore to illuminate and advance to the understanding of the complexity of school teachers using digital technologies in their everyday work practices. 


\section{Research Questions}

- What worldview do teachers in compulsory schools have in relation to digital technologies in everyday education and teaching?

○ How do teachers perceive their professional roles in relation to education and teaching?

- How do teachers perceive student learning?

- How are the uses of digital technologies intertwined with teachers' perceptions of teaching and learning?

- What are the issues of concern that add to increasing the complexity of teachers' use of technology in their everyday work practices?

\section{Research Methodology and Design}

This research has been based upon an ethnographic approach. Ethnographic research has by Madden (2013, p. 17) been defined as "appreciate what it means to be human in particular social and cultural contexts". Applying ethnographic approach to this research allow to gain an understanding of the everyday practices of teachers and their use of digital technologies. The ethnographic approach applied for this research is focused ethnography, also known as short-term approach (Knoblauch, 2005; Pink and Morgan, 2013). Focused ethnography was applied for this research as it allows shorter period filed studies and intense data collection enabling to collect large amounts of data (Knoblauch, 2005; Pink and Morgan, 2013). Focused ethnographic studies further allows for specific study aims based upon circumscribed aspects of the research field, and based upon problem formulated prior to the study (Roper \& Shapira, 2000; Knoblauch, 2005; Pink and Morgan, 2013).

Methods used for data collection have been observations and interviews. Conducting observations, the researcher followed two approaches: one keeping the true role of the researcher hidden for most people and known only to certain "gatekeepers", and the other, the researcher's role and identity was fully open and allowed the researcher to take on a shadowing approach. Combining these observation approaches the researcher can at times observe without affecting the natural setting and at times witness and study the normal life and intimate details of interest (Pole and Morrisson, 2003).

Analyzing the collected data, Soft Systems Methodology, SSM, (e.g., Checkland, 1999) has be used in order to gain a more holistic understanding, as well as organizing and structuring the large amount of data. Additionally, have Cognitive Maps been used in the modeling phase, allowing to map and represent how each different informant think about the situation (Eden, 2004).

To think about and plan the intervention of the research was initially a $\mathrm{SSM}_{\mathrm{P}}$ (short for process) carried out in order to describe the role of the researcher (e.g., 
Checkland \& Winter, 2006). Carrying out an $\mathrm{SSM}_{\mathrm{P}}$ analysis allowed for the researcher to find purposeful level for the $\mathrm{SSM}_{\mathrm{C}}$ (short for content) analysis.

\section{Empirical setting and Data Collection}

The empirical setting consists of two schools located in south of Sweden. In total four teachers have been observed and interviewed. The teachers have been observed for a number of full days following them in preparing classes, in classrooms, discussion with colleagues and students, coffee breaks, etc. Two interviews were conducted with each teacher, closely related in time with the observations, and each interview lasted for approximately 60 minutes. All collected data was transcribed and sent to each teacher for approval.

Additionally, have school leaders from each of the schools been interviewed, and three representatives from the Department of Education at the municipality, as well as the head of the municipal IT-unit. The interviews with school leaders and the representatives from the municipality each lasted for approximately 60 minutes and ware recorded. Transcripts were sent to each respondent for approval.

\section{Research Results}

The results of this research include one highly detailed Rich Picture, number of Purposeful Activity Models (i.e., PQR, CATWOE, and Activity Models) as well as Cognitive Maps the Purposeful Activity Models are based upon. The SSM modeling has been based on each informant and from the outcome of the analysis emerged a summarized Issue Based Model. The summarized Issue Based Model can be considered as a foundation for further discussion in improving the complex situation of teachers' use of digital technologies in their everyday practice.

Additionally, have conclusions to the research questions been achieved, illustrating the complexity of teachers' everyday practice using digital technologies, based on four different teachers, as well as presenting issues of concern that add to the complexity of the teachers' use of digital technologies.

\section{References}

Bates, A.W., 2015. Teaching in a Digital Age: Guidelines for design teaching and learning. Ontario: BCcampus. [Online] Available at: $<$ http://opentextbc.ca/teachinginadigitalage/ $>$ [Accessed 10 July 2015].

Bradley, G., 2006. Social Informatics - From Theory to Actions for the Good Society. In: IFIP International IFIP International Federation for Information Processing, Volume 223, Social Informatics: An In- formation Society for 
All? In: T. Berleur, M. I. Numinen, \& J. Impagliazzo, ed. Remembrance of Rob Kling. Boston: Springer. pp.383-394.

Checkland, P., 1999. Systems Thinking, Systems Practice: Includes a 30 year Retrospective. Chichester: John Wiley \& Sons.

Checkland, P. and Winter, M., (2006). Process and Content: Two ways of Using SSM. The Journal of the Operational Research Society, 57(12), pp.14351441.

Christensen, M.C., Horn B.M. and Johnson, W.C., 2008. Disturbing Class: How Disruptive Innovation Will Change the Way the World Learns. USA: McGraw-Hill.

Dewey, J., 1929. The Sources of a Science of Education, The Kappa Delta Pi Lecture Series. New York: Horace Liveright.

Dillenbourg, P., Järvelä, S. and Fischer, F., 2009. The evolution of research on computer-supported collaborative learning: from design to orchestration. In: N. Balacheff, S. Ludvigsen, T. de Jong, T.A. Lazonder \& S. Barnes, ed. Technology-enhanced learning: Principles and products. Netherlands: Springer. pp. 3-19.

Gaffney, M., 2010. Enhancing Teachers' Take-up of Digital Content: Factors and Design Principles in Technology Adoption, Education Services Australia, [Online] Available at: $<$ http://www.ndlrn.edu.au/verve/ resources/Enhancing Teacher Takeup of Digital Content Report.PDF $>$ [Accessed 23 January 2016].

Geertsema, J., 2014. Technology and the role of the teacher. CDTL Brief, 17(1), pp. 2-3.

Gibson, I. W., 2001. At the intersection of technology and pedagogy: considering styles of learning and teaching. Journal of Information Technology for Teacher Education. 10(1-2), pp. 37-61.

Griffin, J. D., 2003. Technology in the Teaching of Neuroscience: Enhanced Student Learning. Advances in Psychology Education, 27(3), pp.146-155.

Grönlund, Å., 2014. Att förändra skolan med teknik: Bortom "En dator per elev", Örebro: Örebro University, [Online] Available at: <http://www.divaportal.org/smash/get/diva2:706366/FULLTEXT01.pdf> [Accessed $20 \mathrm{Au}-$ gust 2014].

Knoblauch, H., 2005. Focused Ethnography [30 paragraphs]. Forum Qualitative Sozialforschung / Forum: Qualitative Social Research, 6(3).

Laruillard, D., 2012. Teaching as a Design Science: Building Pedagogical Patterns for Learning and Technology, New York: Routledge.

Madden, R., 2013. Being Ethnographic: A Guide to the Theory and Practice of Ethnography. Sage Publications Ltd. 
Mishra, P. and Koehler, M., 2008. Introducing Technological Pedagogical Content Knowledge. Annual Meeting of the American Education Research Association, New York City, March 24-28, 2008.

Näringsdepartimentet, 2011. ICT for Everyone - A Digital Agenda for Sweden, 2011, (N2011.19) Stockholm: Ministry of Enterprise, Energy and Communications, [Online] Available at: $<$ http://www.regeringen.se/sb/d/108/a/181801 $>$ [Accessed 15 May 2015].

Organisation for Economic Co-operation and Development (OECD), 2010. Inspired by Technology, Driven by Pedagogy: A Systemic Approach to Technology-Based School Innovations. Paris: OECD Publishing.

Papert, S. and Solomon, C., 1971. Twenty Things To Do With A Computer, A. I. Laboratory, Massachusetts Institute of Technology, [Online] Available at: $<$ http://hdl.handle.net/1721.1/5836> [Accessed 19 May 2015].

Pink, S. and Morgan, J., 2013. Short-term Ethnography: Intense Routes to Knowing. Symbolic Interaction, 36(3), pp. 352-361.

Pole, C. and Morrison, M., 2003. Ethnography for Education. Berkshire: Open University Press.

Roper, J. M. and Shapira, J., 2000. Ethnography in Nursing Research. Thousand Oaks, Calif: Sage Publications.

Salavati, S., 2013. Novel Use of Mobile and Ubiquitous Technologies in Everyday Teaching and Learning Practices: A Complex Picture. Licentiate, Linnaeus University Faculty of Technology, Department of Informatics. Växjö: Linnaeus University Press

Scardamalia M., Bransfordm J., Kozmam B. and Quellmalzm E., 2010. New assessments and environments for knowledge builders. The University of Melbourne

SFS 2010:800. Skollag. Stockholm: Utbildningsdepartementet, [Online], Available at: $\quad<$ http://www.riksdagen.se/sv/DokumentLagar/Lagar/Svenskforfattningssamling/Skollag-2010800 sfs-2010800/\#K10> [Accessed 24 July 2015].

Sharples, M., Taylor, J., and Vavoula, G., 2007. A theory of learning for the mobile age. In: R. Andrews, and C. Haythornthwaite, ed. The Sage handbook of e-learning research. London: Sage Publications Ltd. pp.221-247.

Skolinspektionen, 2012. Satsningarna på IT används inte $i$ skolornas undervisning. (Dnr 40-2011:2928), [Online] Available at: $<\underline{\text { http://www.skolinspektionen.se/Documents/Kvalitetsgranskning/it/pm-it- }}$ iundervisningen.pdf $>$ [Accessed 15 May 2015].

Skolverket, 2011. Curriculum for the compulsory school system, the preschool class and the leisure-time centre 2011 (Lgr11). Stockholm: Skolverket, [Online] Available at: $<$ http://www.skolverket.se/publikationer?id=2687> [Accessed 17 May 2015]. 
Skolverket, 2013. It-användning och it-kompetens i skolan. [Online] Available at: $<$ http://www.skolverket.se/publikationer?id=3005 $>$ [Accessed 17 May 2015].

Skolverket, 2016. IT-användning och IT-kompetens i skolan. Skolverkets ITuppföljning 2015. (Dnr: 2015:00067), [Online] Available at: $<$ http://www.skolverket.se/publikationer?id=3005> $>$ [Accessed 11 April 2016].

Tondeur, J., Hermans, R., van Braak, J. and Valcke, M., 2008. Exploring the link between teachers' educational belief and profiles and different types of computer use in the classroom. Computers in human Behavior, 24, pp.25412553. 